\title{
THE CONSTRUCTION OF THE CONCEPT OF HOME IN THE EXPERIENCES OF HOMELESS PEOPLE
}

\author{
Dovilè Smiciute \\ Vytautas Magnus University, Lithuania \\ Roberta Motiecine \\ Vytautas Magnus University, Lithuania
}

\begin{abstract}
This paper analyses the construction of the concept of home on the basis of subjective experiences of homeless people. Home as a social construct is revealed by analysing experiences of 5 homeless people. Based on the subjective experiences of homeless people, a qualitative research revealed that safe and private home is one of the main needs of people experiencing homelessness. The construction of home is based on past events and the experience of the reality of the past: the childhood home and created constructs of home, safety and independence as well as certain feelings and emotions. The participants of the research are people experiencing homelessness.
\end{abstract}

Keywords: homelessness, homeless people, home, construction of the concept of home, experiences of homeless people.

\section{Introduction}

Homelessness is a widespread phenomenon in our society. Regarded as the most profound social exclusion, homelessness affects the stages of the existence of every person: it has impact on the identity, relationships, physical and mental health of a person (Sniečkienè \& Dulinskienè, 2014). Homelessness is perceived as a housing problem, closely related to one of the basic needs of people experiencing homelessness, which only increases with age (Sadauskas, 2008). People who do not have a permanent and stable place of residence often spend the night in stairwells, basements, or district heating tunnels. Having no place to live, homeless people lose their sense of self-worth and their ambitions, which leads to the feeling of futility when people become less active and do not take care of themselves.

In 2018, the new law on the declaration of the place of residence came into force. In accordance with Article 6, of the Law on the Declaration of the Place of Residence of the Republic of Lithuania (Valstybès žinios (Official Gazette) No. 21693), for a maximum term of 12 months, homeless people are entered, according to a municipality in which they reside, into the records of people who have not declared their place of residence. However, after 12 months, in order to 
register in the municipality, these people must provide the address of their actual place of residence and information on their economic, social and personal interests to a declaration institution of the territory of the municipality. In accordance with Article 3 of the Universal Declaration of Human Rights, everyone has the right to life, liberty, and security of person. One of the fundamental rights of a person is to have a home; however, homelessness violates human dignity, independence, and fundamental rights of a person.

Home is a place of meaning and value formation, where people can realize their needs and feel loved, safe, and respected. Home is the foundation of stability, physical security, and welfare (Sadauskas, 2014).Pursuant to Article 2.12 of the Civil Code of the Republic of Lithuania, (Valstybès žinios (Official Gazette) No. 74-2262), a place of residence of a person is a domicile of that person: "Being an expression of person's relationship with the state or part of its territory, domicile of a natural person shall be that state or its part, in which he permanently or ordinarily resides, regarding that state or its part to be the seat of his personal, social and economic interests." Home as a social construct is the creation of private world of every person, in which the reality of home is created on the grounds of the ideal of home that a person has. The conception of home is constructed through phenomenological dialectics and the dynamics of social relations in processes. It is assumed that both homelessness and home are social and ideological constructs.

This research focuses on the meaning of home in the experiences of homeless people. The aim of the research is to reveal the meaning of home in the experiences of homeless people. To achieve the aim of the research, the following research question was formulated: How do people experiencing homelessness construct the concept of home?

\section{Home as a social construct}

The understanding of homelessness incorporates a complex and systematic term, that of 'home' (McCarthy, 2018). In positivist models, the terms 'home' and 'homelessness' are interrelated; therefore, the term 'homelessness' can be understood as its literal translation - the lack of home. Home is the most urgent social and economic problem faced by people these days. The concept of home encompasses a physical space, which is understood as a place where human relations and human meaning are created and unfold and as a place where a person finds meaning and value (Tamošaitis \& Daujotyte, 2008). Home is a place where people are welcomed, loved, respected, where they can feel safe and realize their needs. As pointed out by Martinaitis (2007), for a person, home is a place of birth and family formation, which is closely related to the development of new values and the continuity of the family. A person's relationship with home is much deeper than it is assumed (Jonutyte, 2001). Home also covers the circle of life. It is at home that a 
person is born, matures, raises children, and eventually dies. Without home, a person may develop an inferiority complex, so home for a person is always something to strive for (Tamošaitis \& Daujotytė, 2008).

Sadauskas (2008), Kaponienè and Mikulionienè (2004) analyse the living conditions and behaviour of homeless people and investigated causes of homelessness that lead to the social exclusion of people experiencing homelessness. Kocai (2008) examines theoretical issues of homelessness as the social phenomenon and presents different categories and forms of homelessness focusing on the process and stages of becoming a homeless person. Sniečkienè and Dulinskienè (2014) provide social policy for the homeless. In addition, the researchers describe social services and the organization and development of social services in Lithuania. Somerville (1992) analyses the meaning of home in homelessness in order to explore and identify various aspects of the meaning of home and homelessness and explain the political significance of the phenomenon of homelessness, which is expressed in official definitions, legislation and national provisions.

A significant proportion of people experiencing homelessness spend the night anywhere, and only a very small part of them spend the night in storehouses, tents, basements, or district heating tunnels. A house is a clearly privileged being in which a special value of intimacy is perceived. According to Steward (2000), living space is the changing meaning of the mode of life, which expresses a broader sense of theory, locus, identity, and social belonging and often reveals a person's historical past.

Brueckner, Green, and Saggers (2011) provide a different perspective on the meanings of home. For example, psychological interpretations of home are closely related to security, control, independence, personal status, and stability that areprovided and ensured at home. Home is also described as the center of family life, a place of rest, safety, relaxation and freedom, independence, self-expression, and privacy. The authors (2011) state that, besides shelter, belonging and control provided by home, homeless people also seek social and cultural belonging. Somerville (1997) agrees that in literature, meanings of home differ greatly: on the one hand, in psychological and phenomenological terms and, on the other hand, in sociological terms. There are three key concepts that encompass the meaning of home: privacy, which includes visual-spatial relationships; identity, manifested through psychological relationships; and familiarity, which is related to social relationships. Somerville (1997) maintains that our understanding of home is constructed both through the phenomenological dialectics and the dynamics of social relations in processes that can be divided into separate phenomenological and social components.

Home is a social construct. As observed by Berger and Luckmann (1999), human expressivity takes the form of various products of human activity, which can be objectivated and understood as elements of a common world available for the 
creators themselves and other people. There is no way of knowing what home actually exists outside these ideological structural boundaries. Home as a social construct is constructed by a man through language. Berger and Luckmann (1999) state that, as a system of vocal signs, language is "the most important sign system of human society." Understanding language is an essential prerequisite for understanding the reality of everyday life. The detachment of language is determined by its capacity to convey meanings that are not direct expressions of subjectivity.

According to Somerville (1992), a person constructs home by providing certain keywords. For example, shelter corresponds to material conditions, hearth corresponds to emotional and physical well-being, warmth and cosiness at home. The heart signifies social relations, love, and care. The image of subtle home is based on the relationship of mutual love and support. Roots correspond to a sense of individual identity and a source of identity and meaningfulness. As regards the source of identity and meaningfulness, there exists a position in the structure of social relations that is based on a broader cultural and linguistic meaning, which, in turn, creates a broader meaning that reveals the social structure of individual human beings. The keyword 'paradise' corresponds to the ideal of home created by a person in his/her dreams. As claimed by the author (1992), home refers to a material form while, in terms of physical structure, home is seen as a place providing protection. By viewing home as paradise, all positive features of home are idealized and combined.

Berger and Luckmann (1999) believe that it is through language that an entire world can be actualized. Language is capable of bringing back symbols abstracted from everyday experience and turning them into objectively real elements of everyday life. According to Somerville (1992), it can be assumed that these do not constitute the real meaning of home as each individual creates his/her own private world, which is inaccessible and non-existent to other individuals. There is no clear boundary between what is real and what is ideal, as, for example, ideal meaning associated with home is expressed in terms of what home should look like. Every person to some extent shapes the reality of his/her home according to his/her ideal of home.

In conclusion, both home and homelessness are complex and multifaceted concepts. Moreover, home and homelessness are ideological and social constructs. As maintained by Somerville (1992), these concepts combine cognitive and emotional meanings, and these meanings encompass complex and variable differences between what is ideal and what is real. Home and homelessness are considered as being socially constructed both as imaginary ideals and as experienced and intellectual reality. 


\section{The accessibility of social services for homeless people}

Pursuant to Article 3 of the Law on Social Services of the Republic of Lithuania (Official Gazette) No. 17-589), social services are the services aimed at providing assistance to a person (family) who, by reason of his/her age, disability, social problems, partially or completely lack, have not acquired or have lost the abilities and possibilities to independently care for his/her private (family) life and to participate in society. The objective of social services is to create conditions for a person to develop or to enhance the abilities and possibilities to independently solve his/her social problems, maintain social relations with society, overcome social exclusion, and participate in social life.

Anderson (2010) states that the provision of services for people experiencing homelessness should focus on the needs of potential service users and should support pathways out of homelessness, but not make homelessness more tolerable. According to Anderson (2010), the range of services provided for homeless people and their needs can be identified straightforwardly; however, the provision of these services is not straightforward. In Lithuania, homeless people can have access to social services, which are classified in the Catalogue of Social Services (2006) into two types according to their characteristics. General social services are provided without permanent assistance by specialists to a person who seeks to develop his/her abilities to independently care for his/her private or family life and to participate in society. These services are provided in service institutions or in a person's home, and they include information, counselling, mediation and representation, organization of catering, provision of necessary clothes and footwear, organization of personal hygiene services, organisation of transportation, social and cultural services, and other social services. Meanwhile, special social services include all social services that are provided in cases when general social services are no longer sufficient. The objective of special social services is to restore a person's ability to take care of him/herself or a member of his/her family, to satisfy vital needs and, by providing complex services, integrate a person into society. Special social services are divided into social attendance and social care. Social attendance means the totality of services aimed at providing a person with complex assistance in social service institutions or at home, which does not require permanent attendance by specialists.

Ivanauskiene and Gončiarova (2017) note that it is the state that should ensure the provision of high-quality and effective services to homeless people and the preservation of their rights and dignity. As maintained by Busch-Geertsema and Sahlin (2007), hostels are the main place of the provision of services for people experiencing homelessness in all European countries. According to the authors (2007), until the development of a clear policy to mitigate and solve the problem of homelessness, hostels may perhaps be regarded as the oldest institution for homeless 
people. A hostel is a non-residential establishment that provides overnight stay or temporary accommodation for homeless people. In the Catalogue of Social Services (2006) clearly defines the services of overnight stay and temporary accommodation provided in hostels. These services are provided to individuals on the basis of their personal individual characteristics: age, gender, social risk, psychological status, etc. When providing services of overnight stay and temporary accommodation for homeless people, hostels cooperate with addiction treatment centers, mental health centers, social services centers, healthcare institutions, etc. The service of temporary accommodation includes general and special social services provided for individuals who either do not have permanent residence or, even if they have it, cannot benefit from it because of violence or abuse they experience.

The objective of the provision of the services of temporary accommodation is to assist individuals experiencing social exclusion in the complex and consistent process of adaptation and integration into society. Together with temporary accommodation, a person is provided with home environment, essential services, and conditions for independent living. Moreover, in addition to accommodation services, individual activities are offered to recipients of the services. The aim of these activities is to prepare individuals for independent living and encourage them to look for a place of residence, employment opportunities, etc. The service of temporary accommodation is provided for individuals who do not have a permanent place of residence or are in a crisis situation; thus, they are provided with accommodation and complex assistance.

Busch-Geertsema and Sahlin (2007) claim that the purpose, access and physical form of hostels and temporary accommodation vary from country to country and change over time. In many countries, the perception of the role and value of hostels and temporary accommodation has changed. As observed by Sadauskas (2010), counselling and psychological as well as emotional support provided by social workers help homeless people to revive social relations and find inner motivation. Busch-Geertsema and Sahlin (2007) believe that hostels facilitate the provision of social assistance. Hostels are perceived as a form of community where people experiencing homelessness can communicate with each other. However, at the same time, hostels provide protection and control since, in these places, the behaviour, health, and personal contacts of individuals are under control. In addition to services provided by hostels, homeless people can also benefit from services provided by non-governmental organisations. Evangelista (2010) did a study of definition of home and revealed that in most cases government policies are focused on financial issues, rather than to the entitlements to people. Cronley (2010) discussed homelessness in the framework of social problems within society, but an author did very important conclusion that only when structural problems such as unemployment or poverty will be connected with personal problems only than interventions and services will be effective. 


\section{Research methodology}

A qualitative study was chosen to reveal the research object. Homelessness as the research object has received little scholarly attention in research on social work; thus, this field of research has not been widely and systematically studied. In order to reveal the construction of the concept of home in the experiences of homeless people, the semi-structured interview method was used to collect research data. During the research, the order of the prepared questions was not followed; the questions were freely swapped to address the situation. The research was based on convenience sampling. The sample was drawn up from the most accessible unit, in cooperation with one of the day centers for homeless people established in one of the largest cities in Lithuania. The survey was conducted between November 2018 and February 2019 and included 6 people experiencing homelessness. For the selection of the research participants, demographic and experience criteria were applied. As for demographic criteria, only male participants aged 30-50, complying with the criteria for family, social, economic status and homelessness experience were invited to participate in the research. As far as the criterion of experience is concerned, only participants who are homeless and do not have a permanent place of residence were invited to take part in the research. After identifying the criteria, in total, 6 participants were purposefully selected for the research.

Characteristics of the research participants were as follows:

1. The research participant Andrius (the name has been changed) is 48 years old, divorced, has a secondary education, and 20 years of service. He maintains a close relationship with his son, who lives abroad. Andrius suffers from alcohol addiction.

2. The research participant Ovidijus (the name has been changed) is 45 years old, divorced, has a secondary education, and 11 years of service as a lifeguard. He has been experiencing homelessness for three years. Because of serious injuries, Ovidijus is unemployed. He maintains a close relationship with his mother, who is struggling in her life. He has no more relationships with the immediate environment. He served a long period of imprisonment. Ovidijus suffers from alcohol addiction.

3. The research participant Marius (the name has been changed) is 35 years old, divorced. He has been a homeless person for 3 years. He does not maintain any relationship with his immediate environment. Marius is unemployed. He suffers from alcohol addiction and health problems associated with it.

4. The research participant Edgaras (the name has been changed) is 45 years old, divorced, and has a secondary education. He has been a homeless person for almost 3 years. At the meantime, Edgaras is unemployed. His mother is dead, and, since childhood, he has not had any contact with this 
biological father. Edgaras maintains a closer relationship with his daughter and grandchildren. He lives in a hostel. Edgaras suffers from alcohol addiction.

5. The research participant Gintaras (the name has been changed) is 49 years old, has a secondary education, has no work experience as he served a long period of imprisonment. Gintaras is unmarried, has two children, who live in England. He does not have any close contact with his children and the immediate environment. For 20 years, he has experienced homelessness. Gintaras suffers from alcohol addiction.

6. The research participant Henrikas (the name has been changed) is 40 years old, has a secondary education, and, for a long time, worked as a driver. $\mathrm{He}$ is unmarried, has a son, who lives in Germany. Henrikas does not maintain a close relationship with his son and his immediate environment. Currently, he is staying in a hostel. He has been homeless for two months. Henrikas does not suffer from alcohol addiction.

The research was based on the ethical principles described by Flick (2014) and the principles of the Code of Ethics of Social Workers. To be more specific, during the research, the inherent right and dignity of the research participants were respected; the work was done with honesty, impartiality, reliability, and empathy with respect to the participants; the confidentiality of data obtained about the research participants and responsible use of the data for writing the article were ensured. With the consent of the research participants, the interviews were recorded on a voice recorder. The longest interview took 39:49 minutes, whereas the shortest, 17:59 minutes. When collecting data, the participants were approached in a polite manner, they were encouraged to speak freely and not to be afraid to dream. All this was done in order to provide more comfortable conditions for the research participants. The collected research data was analysed on the basis of general steps of data analysis distinguished by Krysik and Finn (2010): conceptualisation of data; creation and development of history; maximisation of accuracy when validating findings and publishing research findings.

\section{Research results}

The meaning of home in homelessness. Homelessness literally means the lack of home. Sadauskas (2008) notes that home is the basis for stability, physical security, and welfare. Home is one of the basic needs of people experiencing homelessness, which only increases with age. Tamošaitis and Daujotyte (2008) state that today it is the most urgent social and economic problem faced by humans. People who do not have a permanent and stable place of residence, according to Sadauskas (2008), often spend their nights in stairwells, basements, or district 
heating tunnels. The analysis of the research data showed that home in homelessness is a key concern, when a homeless person has no choice but sleep in abandoned buildings or hostels.

As pointed out by Vosyliūte (2015), only a small number of homeless people spend the night in stairwells, basements, or district heating tunnels. For example, Gintaras (49 y/o) finds shelter in a stairwell, where he has a blanket, a pillow, and a sleeping bag. The research participant states:

...Now I spend more time in the stairwell. Almost throughout the whole winter. As that woman knows me, she does not throw me out. Other neighbours have not noticed yet...they know that there is someone here. ...one day they came in the morning, knocked, and said:

'Take the tea. '...I was even surprised! ...So, in such places I spend my time. I don't know how much I will stay here... [Gintaras, 49 y/o]

During the first weeks of homelessness, Henrikas (40 y/o) lived in stairwells, where sleeping was difficult and uncomfortable. As noted by the research participant Henrikas (40 y/o), the main criteria when searching for a stairwell include: no lock, no door code, but it should have a radiator. The research participant Henrikas told the following:

So, you sit down on the stairs, and you need to find a stairwell there, so that you could enter it because most of stairwells are locked nowadays... a radiator in a stairwell would also be a plus...you simply lean yourself against the radiator and sleep. Your butt hurts, excuse the saying, and those legs are constantly bent as you can't stretch them. You put some newspaper on those stairs...So you somehow stretch the leg... But actually, you are noticed and that's all. [Henrikas, $40 \mathrm{y} / \mathrm{o}$ ]

Kocai (2017) observes that homeless people do not have constant places to stay. However, the analysis of the research data revealed that people experiencing homelessness tend to stay in the same stairwells longer because they are acquainted with those places and know that it is safe there. Andrius' (48 y/o) home in homelessness is seasonal. In summer, the research participant sleeps in a tent, which is dismantled in the morning and safely locked in a supermarket locker. As the evening approaches, he sets up the tent again. In winter, the research participant spends nights in places where he could hide from the cold. Andrius (48 y/o) says:

... in summer... you have a tent. Well, when it's warm in summer, you can sleep in a tent. I have my own tent. I set it up and then dismantle it. I get up in the morning, dismantle my tent and bring it to the supermarkets "Maxima" or "Iki" and lock it the supermarket locker. Then, in the evening, I come and take it and set it up and sleep in it at night. ...in winter...well, I sleep in a basement or somewhere else...in hallways or somewhere in stairwells. ... you won't sleep outside in winter. It's really cold outside in winter. [Andrius, $48 \mathrm{y} / \mathrm{o}]$

As noted by Vosyliūte (2005), a large proportion of homeless people spend the night anywhere. In the course of the analysis of the research data, it was observed that people experiencing homelessness also have permanent places where they find shelter. Abandoned houses are the most common permanent living places for homeless people. The research participant Ovidijus (45 y/o) finds shelter in an 
Smiciute \& Motiecine, 2020. The Construction of the Concept of Home in the Experiences of Homeless People

abandoned house in Savanoriu prospect. The house is entered through the roof. There is a bed in this house, but it is very cold there, even colder than outside. The research participant is happy that, even it is cold there, at least it does not rain inside and the wind does not blow. As he tells himself:

...there is a board up house at the end of Savanoriu prospect. Actually, at the beginning of it! The house is board up so I enter it through the roof. There is a bed there...It's very cold there, really very cold! It's colder there than outside! But you are protected from rain, snow, and wind. [Ovidijus, $45 \mathrm{y} / \mathrm{o}$ ]

Marius' (35 y/o) permanent living place in homelessness is a guard cabin without any amenities. When asked what is in the cabin, the research participant mentioned a bed, a table, and a cupboard:

Once it was a guard cabin. ...A bed, a table, and a cupboard. That's all you can find there. [Marius,35 y/o]

Other research participants use services provided by hostels. Hostels, according to Busch-Greetsema and Shalin (2007), are an essential element of services provided for homeless people in all European countries. A hostel is a non-residential establishment that provides services of overnight stay or temporary accommodation for homeless people. Hostels also provide protection and control. The research revealed that homeless people use services provided by hostels in order to avoid living on the street or in abandoned buildings. Homeless people state that they have no choice but use services of temporal accommodation. The research participant Edgaras (45 y/o) speaks openly:

It seems to be a forced thing...I have no other choice. I'm sure, in summer, I would go somewhere in the forest, and I would sleep somewhere under the bushes... [Edgaras, 45 y/o] Henrikas (40 y/o) also uses services provided by the hostel. However, when asked to tell a little bit about the hostel, he was reluctant to speak, only mentioned that there was a room and six beds there:

Well, a room and six people... [Henrikas, $40 \mathrm{y} / \mathrm{o}$ ]

The analysis of the interview data of Henrikas (40 y/o) and Edgaras (45 y/o) revealed that they receive services of temporary overnight stay. In accordance with the Catalogue of Social Services (2006), this social service can be used once for up to three days. It can therefore be presumed that home in homelessness is the most urgent problem. In homelessness, home is divided in the following way: nonpermanent places of residence, which include life in stairwells, basements, corridors, or parks; permanent places of residence, such as abandoned buildings or hostels, which ensure temporary night stay or temporary accommodation for people who do not have permanent place of residence, and in these places they can protect themselves from living on a street.

Construction of a dream home. Home, like homelessness, is a social construct that is constructed through language, which, according to Bergen and Luckamn (1999), enables us to actualize the world. As observed by Steward (2000), living space is associated with the meaning of the changing mode of life, which often 
expresses a person's historical past. Somerville (1997) notes that there are different approaches to the meaning of home, such as psychological, phenomenological, and social approaches. The author (1997) argues that every person constructs home by using specific words. The analysis of the research data revealed that, when talking about the construction of a dream home, the research participants divided into two groups: one group of the participants constructed their dream home on the basis of past stories and dream ideals, whereas the other group of the participants constructed their dream home through imaginary ideals.

For the research participant Ovidijus ( $45 \mathrm{y} / \mathrm{o}$ ), a dream home is a flat where he would live with his family that would bring happiness and love:

A flat...even of one room....well, but if I had more than one child, then, obviously, one room wouldn't be enough. ...The most important thing is to have a family! ... [Ovidijus, $45 y / o]$

The construct of the dream home of the research participant Ovidijus (45 y/o) is based on the reality experienced in the past. It can be maintained that a dream home is constructed on the basis of one's childhood home in the past. The research participant told the following:

This was truly home full of love! Everyone loved me there...I lived in a free-room flat.

Five people lived in the flat. ...One room was for me and my grandpa. My grandma lived separately, and my parents had a separate room. I had good life there, really good life! [Ovidijus, $45 \mathrm{y} / \mathrm{o}$ ]

It can be noticed that the research participant Ovidijus (45 y/o) associates his childhood home with love and family, which provided the basis for living safely with the loved ones. The research participant Gintaras (45 y/o) is dreaming of owning a small but tall house, which he associates with freedom and independence. The research participant states:

It can be small. Several rooms...Tall...A private small house, a private yard, a pond...flowers blooming everywhere... But I know that a cop won't come, and that a soldier won't trample my grass with his boots.... [Gintaras, 45y/o]

As observed by Gintaras, a dream home should be located in a remote and quite area:

It would be better if the house was a kilometre away from the city. So that we could enjoy peace. Not far from, for example, a forest. ... [Gintaras, $45 \mathrm{y} / \mathrm{o}$ ]

The research participant Gintaras (45 y/o) also constructs his dream home on the basis of past stories related to the serving of the sentence in prison. When constructing his dream home, the research participant Gintaras (45 y/o) expresses his experience of the past in the following words:

But I know that a cop won't come, and that a soldier won't trample my grass with his boots [Gintaras, $45 \mathrm{y} / \mathrm{o}$ ]

Henrikas (40 y/o) is dreaming about his home very timidly, but, encouraged not to be afraid to dream, he told that he wanted to own a private house with a yard: A flat would be fine for me. Of course, a house would be better. Well, as for me, I don't need.... a house of two floors, it is too big. ...Well, of course, I would like to have a private 
Smiciute \& Motiecine, 2020. The Construction of the Concept of Home in the Experiences of Homeless People

yard, so to say, to go out in summer and to barbecue... Well, you can wish for many things [Henrikas, 40m.]

When asked about what the house should contain and how it should look like, the research participant said that he wanted to have a clean home and live in it with his family:

...I would like to have a clean and tidy home. A woman, of course, and a family... Work.

That's all what I need. [Henrikas, 40 y/o]

Henrikas (40 y/o) is also constructing his dream home on the basis of his imagination. When talking about home, he clearly highlights cleanliness and order. The research participant says:

Well, I really liked luxury, I liked my home to be kept clean and in order. My home used to be clean, so to say... Well, my home used to be an ordinary tidy home. [Henrikas, y/o] It can be assumed that the construction of home is influenced by past experiences and present reality. This can be seen in the stories told by the research participants and in the comparisons that they made. The research data show that the construction of a dream home is associated with the childhood home and also with the created images of home. Other research participants construct their dream home on the basis of imaginary ideals and their own idea of home. In this case, the construct of a dream home does not relate to experiential ideals and past stories. For instance, Andrius' (48 y/o) construct of a dream home is associated with an image of a fairy tale or an ideal home. According to Somerville (1997), an ideal home conveys a material form of a home together with its positive characteristics. The research participant Andrius is dreaming of a two-storey house with a large yard, two garages, a garden, and a summer house:

...my dream home...I would like to have in Kaunas. Let's say, in Žaliakalnis district.

To have a two-storey house. A beautiful house, of course! To have two garages in the yard and a summer house. Plus, a greenhouse, to grow cucumbers or tomatoes...of course, to have a good and beloved girlfriend... and a dog in the yard. The dog should be a wolf dog, only a wolf dog! And...there should be a kennel for the dog... Well, in my dreams, I have such a fairy tale house... and warmth should be felt in my home...there should be a garden, several apple trees and pear threes...my dream house has a large yard... [Andrius, 48 y/o] In his dream house, Marius (35 y/o) would like to have everything that a person needs most: a bed, a closet, and a TV set. He says:

Well, a bed, a table, a closet, a TV set. That's all that I need....I don't need apartments. I don't need it. I am an ordinary person; I don't need it. [Marius, 35 y/o]

Encouraged not to be afraid to dream, the research participant states that if he could afford it, he would like to have a summer house near Kaunas, so that there would be good public transport connections.

Well, if I could afford it... a summer house...but somewhere near Kaunas. So that there would be a bus to this direction. [Marius, 35y/o]

The research participant Edgaras (45 y/o) is dreaming about a small and cosy log village house: 
... a privately owned house, such as a village house, a wooden, log house, very cosy... and small, of course. [Edgaras, 49 y/o]

When asked about what that village house should contain, the research participant mentions a fireplace. According to Somerville (1997), a fireplace symbolizes emotional and physical well-being and provides warmth and cosiness to home. The research participant also adds that his home should contain rustic attributes:

A fireplace, it gives a lot of cosiness to home. Probably that is one of the elements...in the yard...well, you could build a small bathhouse and dig a pond, so that you could swim in it... all these attributes, very rustic... [Edgaras, $45 \mathrm{y} / \mathrm{o}$ ]

When inquired about where his dream house should be located, Edgaras (40 y/o) answers that in the forest or by the river:

In the forest, of course! In the forest or by the river. ... [Edgaras, 45m.]

Thus, as the research data show, homeless people construct their dream homes on the basis of past stories, present reality and imaginary ideals. Those research participants who construct their dream home on the basis of past stories or present reality, actually refer to difficult and painful stages of their life. The construction of a dream home, in the same way as the creation of a private and authentic world of each individual, is based on different ideals of home. The research data revealed that the research participants are dreaming about small and minimalist but safe homes.

The construction of the word 'home'. Home, according to Tamošaitis and Daujotyte (2008), is a place of human meaning and value, which is not only a physical space but also a place where human relations and human meaning are created and unfold. The authors state that home is a place where a person is welcomed, respected, loved, where he/she feels safe and can realise his/her needs. Studies carried out by Somerville (1997) revealed the main meanings of home: home is seen as the center of family life and as the place of rest; home is associated with safety and relaxation, freedom and independence, freedom of expression, continuity and permanence, etc. The analysis of the research data shows that the meaning of the word 'home' for homeless people is associated with love and warmth, comfort and fortress, property, security, and freedom. Home for the research participant Andrius (48 y/o) is a place where people do not feel homeless, and, because of this, they do not waste their time and do not need to vagabond. According to him, it is a place where people can feel warmth and love:

A home...you can come home and you...you don't need to wander on the streets and vagabond... You come to your own home, not to a stairwell...so, a home is a place where you can live... as a person who is loved, as an ordinary person. Like all those people who live with love...live with love and warmth...You live in warmth... and you don't feel that you are homeless or whatever...your own home, and you live in it, and you own it. So, this is what I call home. [Andrius, $48 \mathrm{y} / \mathrm{o}$ ]

Comfort and fortress, "My home, my fortress!". This is how the word home is understood and described by the research participant Ovidijus (45 y/o). According 
Smiciute \& Motiecine, 2020. The Construction of the Concept of Home in the Experiences of Homeless People

to the research participant, it is a feeling of inserting the key into the lock, it is when a person can lock or unlock the door, when he/she goes to bed and realizes that he/she is at home. Ovidijus says:

Comfort. Fortress! No wonder that it is said, "My home, my fortress!" When you come home, and you can put the key in the lock and lock the door...You lie down, and you know that...you, you are at home... When you can feel relaxed. When you know that it's your corner, and you have it...No one will throw you out. [Ovidijus, 45 y/o]

The word 'home' is also understood as property. For Marius ( $35 \mathrm{y} / \mathrm{o})$, home is a place where a person can sleep and eat, and where a person can feel calm and peaceful because he/she knows that it is his/her own property:

When you know that you can come, and you know that you have a place to sleep and eat. And you know that it's yours. Well, I don't know, such a place is probably called home. [Marius, $35 \mathrm{y} / \mathrm{o}$ ]

Safety. For the research participant Edgaras ( 45 y/o), the word 'home' means safety and confidence for future, and it gives rise to positive feelings, such as peace, trust, and safety. In his opinion, home is an essential thing for any human. Edgaras notes:

Safety. First of all. Some assurance for future... that you have something that belongs to you; you have your own roof over your head. That's an essential thing. [Edgaras, $45 \mathrm{y} / \mathrm{o}$ ] Gintaras (49 y/o) associates the word 'home' with the second heart. Home, for him, is a place where a person can feel free and can rest without any disturbance. Gintaras says:

...it's impossible to live without a roof over your head. To have a home is the same as to have the second heart!...It is very bad when a person doesn't have a home. But when you have a home, you can go out, you can work if you need, then come back home, and no one gets on your nerves... you feel free. You turn on the TV, read a newspaper or a book. And you know you can rest and not be disturbed!... [Gintaras, 49 y/o]

For Henrikas (40 y/o), the word 'home' means safety and property. Home, according to him, is a place where you can get a good night's sleep and where no one will throw you out. Henrikas says:

... if you have a home, you have a place to come, so to say, and get a good night's sleep; no one will throw you out of that place or tell you anything...you are a master to yourself.... [Henrikas, 40m.]

When asked if a home is a place where a person can feel safe, the research participant answered 'yes'. For him, this place is associated with warmth and comfort. Henrikas notes:

It's a warm and cosy place.When you want, you open the door or close it. [Henrikas, y/o]

To sum up, homeless people have different understandings of the word 'home'. Some of them associate it with safety and independence, for others, 'home' means love, warmth, comfort, and fortress. However, similarities can be noticed in the answers provided by all research participants. The research data revealed that home 
is a place where a person can come back and have a good night's sleep, where he/she can eat and realise that it belongs to him/her and that he/she is a master of this place.

\section{Conclusions}

A safe and privately-owned home is one of the most important needs of people who experience homelessness. Homeless people often spend their nights anywhere; therefore, home for a homeless person is always something to strive for; it is a place where he/she could feel safe, loved, valuable and also satisfy and realise his/her needs. Home, like homelessness, is a social construct. The construction of the concept of home is based on past stories, experiential intellectual ideals, and imaginary ideals. Moreover, the concept of home is constructed on past events, experienced past reality, which is associated with the childhood home and created images of home. Every research participant constructs the concept of home in a different and distinct manner because every person creates his/her individual and private world following his/her own ideal of home or reality that is inappropriate to others. Homeless people have different understandings of home: for some, home means safety and independence; for others, it is associated with feelings and emotions. It can be concluded that homeless people view home as a place where they can return, have a good night's sleep, eat and feel that they are the masters of their own home.

The qualitative research revealed that people experiencing homelessness face not only challenges related to the satisfaction of their basic needs but also safety challenges. However, one of the main challenges faced by homeless people is the satisfaction of physiological needs, i.e. food, water, and a place of residence. Homeless people may feel unsafe because of assaults, abuses, and thefts that they face, which adversely affects their self-esteem, motivation and stability and which, in turn, makes them go downhill. As observed from the experiences of the homeless people, they can feel safe only when they can spend their nights at their friends' place.

Though, in this article the attention was focused only on the home as a social construction, the researchers, who are doing researches in this field may continue qualitative studies, aiming to reveal how the different type of addictions make influence that persons become homelessness. Also, good practices from the perspective of whose who are providing social services may be revealed.

\section{References}

Berger, P., \& Luckmann, T. (1999). Socialinès tikrovès konstravimas. Pradai: Vilnius.

Brueckner, M., Green, M., \& Saggers, S. (2011). The trappings of home: Young homeless people's transitions towards independent living. Housing studies, 26(1), 1-16 
Smiciute \& Motiecine, 2020. The Construction of the Concept of Home in the Experiences of Homeless People

Cronley, C. (2010). Unraveling the Social Construction of homelessness. Journal of Human Behaviour in the Social Environment, 20(2), 319-333.

Evangelista, G.F. (2010). Poverty, homelessness and freedom: an approach from the capabilities theory. European Journal of Homelessness, 4.

Flick, U. (2014). An Introduction to Qualitative Research, 5th edition. Sage Publications: London. Jonutytė, J. (2001). Namai: bereikšmė ir daugiaprasmè veiksmo erdvė. Žmogus ir žodis.

Kocai, E. (2012). Benamystė kaip socialinis psichologinis reiškinys: benamių savastis, vertybès, lūkesčiai.

Kocai, E. (2017). Gatvès benamiųgyvensena: Vilniaus miesto „bastūnų“ kasdienio gyvenimo ypatumai. Socialinis ugdymas, 47(3).

Lietuvos Respublikos gyvenamosios vietos deklaravimo įstatymas, No.XIII-961, Vilnius.

LR Socialinių paslaugų katalogas, Valstybės žinios (Official Gazette), 20-04-2006, No. 43-1570.

Martinaitis, M. (2007). Namai-rojausdarželiomodelis. Žmogus ir gyvenamoji aplinka: konferencijos medžiaga, 2007, 25-30.

McCarthy, L. (2018). (Re) conceptualising the boundaries between home and homelessness: the unheimlich. Housing Studies, 33(6), 960-985.

Respublikos, L. (2000). Civilinio kodekso patvirtinimo, įsigaliojimo ir igyvendinimo įstatymas. Valstybès žinios (Official Gazette), (74-2262);

Sadauskas, J. (2008). Benamiai, kaip socialinès atskirties grupè. Socialinis darbas, 7(1), 127-136.

Snieškienè, D., \& Dulinskienė, I. (2014). Homelessness in Lithuania: policy and research. European journal of homelessness, 2014, 8(2), 211-230.

Somerville, P. (1992). Homelessness and the meaning of home: Rooflessness or rootlessness? International Journal of urban and regional Research, 16(4), 529-539.

Somerville, P. (1997). The social construction of home. Journal of architectural and planning research, 226-245.

Steward, B. (2000). Living space: the changing meaning of home. British Journal of Occupational Therapy, 63(3), 105-110.

Tamošaitis, R., Daujotytė, V., Šliogeris, A., \& Rubavičius, V. (2008). Namai ir benamystè literatūroje. Lietuvos rašytojų sajungos menraštis „Metai”, No. 6. Retrieved from http://www.tekstai.lt/rss/492-2008-nr-6-birzelis/3397-namai-ir-benamyste-literaturoje,

Visuotinè žmogaus teisių deklaracija, Nr. 68-2497.

Vosyliūtè, A. (2005). Visuomenès pakraščiužmonès: praradimaiirviltysStraipsniųrinkinys. Vilnius: LSTC.

Vosyliūtè, A. (2015). Vargetos: ieškant gyvenimo sąlygų ir savęs. Socialinis darbas, 4(2), 33-41. 